\title{
Effect of phenological phase of dry grazing pasture on fatty acid composition of cows' milk
}

\author{
Dusica Radonjic ${ }^{1 *}$, Nenad Djordjevic ${ }^{3}$, Bozidarka Markovic ${ }^{1}$, Milan Markovic ${ }^{1}$, Danijela Stesevic ${ }^{2}$, \\ and Zora Dajic-Stevanovic ${ }^{3}$
}

${ }^{1}$ University of Montenegro, Biotechnical Faculty, Mihaila Lalica 1, 81000, Podgorica, Montenegro.

"Corresponding author (dradonjic5@gmail.com).

${ }^{2}$ University of Montenegro, Faculty of Science and Mathematics, Džordza Vasingtona bb, 81000, Podgorica, Montenegro.

${ }^{3}$ University of Belgrade, Faculty of Agriculture, Nemanjina 6, 11080, Belgrade, Serbia.

Received: 8 October 2018; Accepted: 16 January 2019; doi:10.4067/S0718-58392019000200278

\begin{abstract}
The fatty acid content is a very important feature of the milk that affects the health of consumers. The aim of this study was to estimate cow's milk fatty acid composition in early vegetative, late vegetative and reproductive phase, with the simultaneous determination of the pasture biomass chemical and botanical composition. The research was conducted on Agrostis castellana semi-natural dry grassland in the vicinity of Podgorica, Montenegro. Cows were put to grazing during the whole experimental period. This pasture was assessed as moderate to good quality and botanically diversified. The chemical composition of the grassland biomass changed with the maturity phase. A significant increase in the content of $\mathrm{DM}$, crude fiber, fat and a decrease in crude protein content were determined throughout three phenological phases $(\mathrm{p}<$ 0.05). The content of total milk fat did not show significant variability during first two phases, but it did in the third phase. The content of milk fat and protein was high in all phases, although it is a dry pasture with a poor quality of biomass in the third phase. The content of majority saturated fatty acids (SFAs) increased with grass maturity, while total content of monounsaturated fatty acids (MUFAs) decreased. The polyunsaturated fatty acids (PUFAs) content kept the same level up to the reproductive phase. The phenological phase significantly influenced the content of fatty acids in the third phase $(\mathrm{p}<0.05)$. A notable number of SFAs, MUFAs end PUFAs had the highest content in the second phase.
\end{abstract}

Key words: Botanical composition, fatty acids, milk, pastures, phenological phase.

\section{INTRODUCTION}

Semi-natural meadows and pastures constitute a very important part of the agricultural land of Montenegro. According to Monstat (2016) meadows and pastures constitute $94.33 \%$ of the total utilized agricultural land of Montenegro. The biodiversity of pastures has been little studied throughout Southeast Europe, including Montenegro (Stesevic and Cakovic, 2013). Natural pastures in Montenegro cover poorer land, inadequate for intensive exploitation. The characteristics of these pastures are low yield and unfavorable floristic composition. They are mostly on steep slopes and shallow lands. It is most common in classes III and IV of soil fertility (Fustic and Djuretic, 2000). Milk production, as well as livestock production in general, in Montenegro is largely based on the use of pasture.

The chemical composition of the pasture biomass varies depending on the botanical composition of pastures and phenological phase (Bovolenta et al., 2008). All changes in the pasture reflect on the milk composition, especially on the milk fat quantity and composition (Bohacová et al., 2009).

Cow milk contains about $87 \%$ water, $4.6 \%$ lactose, $3.4 \%$ protein, $4.2 \%$ fat, $0.8 \%$ minerals and $0.1 \%$ vitamins. The milk composition is continuously changing depending on breeding, nutrition, herd management, lactation stage and season (Tratnik and Bozanic, 2012). 
People are increasingly paying attention to animal fats as an important factor that affects human health. Research shows that the intake of certain unsaturated fatty acids (FAs) reduces the risk of cardiovascular diseases, and certain types of tumors, diabetes, etc. (Descalzo et al., 2012). Some unsaturated FAs may have a potentially negative effect on health.

The most prevalent FAs in milk are saturated (SFAs), then monounsaturated (MUFAs) and at least polyunsaturated (PUFAs) (Frelich et al., 2009). The differences in the composition of milk FA related to the composition of the diets and the use of pasture are reported by numerous authors (Chilliard et al., 2007). The pasture grazed cow's milk is characterized by higher PUFAs and MUFAs concentrations, and lower SFAs concentrations comparing to concentrate feeding. Nutrition is the most important factor affecting the composition of FA in milk (Hanus et al., 2016). Breed, lactation phase and individual variations of cows are the most frequently studied factors that are often observed in combination with other factors (Samková et al., 2018). The effect of the breed on FA composition is generally small in comparison with the effects of nutrition and individual differences between animals (Sasanti et al., 2015; Samková et al., 2018). Many research shows significant impact of phenological phase on milk FA content (Bohacová et al., 2009; Gorlier et al., 2012).

In addition to botanical composition of pastures, which is recognized as a key factor (Ferlay et al., 2008), there are other factors that may influence the profile of milk FA such as the grazing management and animal characteristics (Coppa et al., 2015) and the phenological phase of pasture (Ferlay et al., 2008; Glasser et al., 2013). All changes that occur in pastures can affect the quality of milk and hence the quality of dairy products (Descalzo et al., 2012).

The aim of this study was to estimate changes in pasture and milk composition on natural pastures and at the same time determinate its botanical composition in three phenological phases. This type of pasture, Agrostis castellana dry pasture, has not been studied in this area, also, or even beyond.

\section{MATERIALS AND METHODS}

\section{Study site}

The research was conducted in the semi-natural pasture in the vicinity of Podgorica, since early April to mid-July 2017. Samples from 20 multiparous cows were taken (Holstein Friesian, Brown Swiss, Simmental and crossbreed). Two family dairy farms were selected for the examination. Those farms are characterized by an extensive livestock system, which is mostly reflected in poorer nutrition in the winter based on hay obtained from natural meadows with small addition of concentrated nutrients. Cows were fed by grazing on natural pastures from the beginning of vegetation. The first milk and grass sampling was $10 \mathrm{~d}$ after the cows started with grazing in order to adapt to a new feed. The interval between phases was $45 \mathrm{~d}$. The first phenological phase represents the early vegetative phase. The second phase is late vegetative phase and the third phase is the reproductive phase. The grassland biomass samples were also taken three times, in parallel with milk samples. Grassland is exclusively used for grazing, since mowing is not performed. The dry grassland of Agrostis castellana was selected for experimental research $\left(42^{\circ} 50^{\prime} 19.5^{\prime \prime} \mathrm{N}, 19^{\circ} 27^{\prime} 35^{\prime \prime} \mathrm{E} ; 78 \mathrm{~m}\right.$ a.s.1.)

\section{Botanical assessment}

Data on floristic composition and structure of plant communities were gathered using the standard Braun-Blanquet methodology (Braun-Blanquet, 1964). The releves on pasture were taken inside the 3 plots, size $10 \times 10 \mathrm{~m}^{2}$, in three different aspects: mid of April (early vegetation phase), late May (late vegetation phase), early July (full reproductive phase). Identification of plant material was performed with standard keys for plant identification (Tutin et al., 1964-1993), while the nomenclature follows Euro+Med (2006). Herbarium material is deposited in the herbarium collection at the University of Montenegro (TGU). The quality of pasture was determined as a certain proportion of functional groups, such as grasses (Poaceae), legumes (Fabaceae) and other herbs.

\section{Grassland biomass chemical composition analysis}

Samples of forage were collected from the pastures according to procedure AS-1064 (2012), and chemical analyses were done according to AOAC (2000). Samples were taken from eight locations at random. The forage from $1 \mathrm{~m}^{2}$ area was removed. All collected forage was mixed and a representative sample for analysis was prepared. The following parameters of pasture were determined: moisture content by the gravimetric method; crude protein content based on total $\mathrm{N}$ content by Kjeldahl method and multiplication by factor 6.25 ; total cellulose content of the fiber extraction device 
according to the manufacturer's procedure (Fibretherm, C. Gerhardt GmbH, Königswinter, Germany) and in accordance with the appropriate method according to Henneberg-Stohmann; total fat content of the fat extraction device, according to the manufacturer's procedure (SOXTHERM, C. Gerhardt $\mathrm{GmbH}$ ) and in accordance with the Soxhlet method; the total ash content by the gravimetric method by burning the sample at $540-600{ }^{\circ} \mathrm{C}$. All parameters of the grass chemical composition were analyzed in the Laboratory for Animal Nutrition of the Biotechnical Faculty, University of Montenegro, Podgorica, Montenegro.

\section{Milk chemical composition}

From each cow, two samples were taken according to ISO 707:2008(E) IDF 50:2008(E) (ISO-IDF, 2008), one for basic chemical analyses and the other for determining the content of fatty acids (FA; $2 \times 50 \mathrm{~mL}$ ). From the farm to the reception in the laboratory, samples were placed in hand refrigerators, which prevented any change in the quality of milk samples. The analyses were performed by standard and instrumental methods in laboratories, the Dairy Laboratory at the Biotechnical Faculty. Analysis of milk was performed using Combi Foss 5000 instrument (Foss Electric A/S, Hilleroed, Denmark), consisted of MilkoScan 4000 and Fossomatic 5000 basic. MilkoScan operates on the principle of infrared spectrophotometry (IDF Standard 141C, 2000).

\section{Determination of fatty acids}

The FA content of the milk was determined by gas chromatography. Milk samples were immediately stored in refrigerators with ice and transferred to freezers where they were stored until analysis at a temperature of $-40{ }^{\circ} \mathrm{C}$. Determination of the FA content was carried out at the Center for Ecotoxicological Research in Podgorica, using the gas chromatograph with mass detector (GCMS-QP2010 Plus; Shimadzu, Kyoto, Japan), on column SP-2560 fused silica capillary column 100 $\mathrm{m}, 0.25 \mathrm{~mm}$ ID, $0.20 \mu \mathrm{m}$ film. The results are expressed in $\%$ as a proportion of individual FA methyl esters in the total FA content. The content of saturated and unsaturated fatty acids (C 4:0 to C 24:1) was determined. Methyl esters were analyzed according to ISO Standard 15885 (ISO-IDF, 2002).

\section{Statistical analysis}

Statistical analysis included the calculation of basic statistical parameters. The statistical significance of results was tested by ANOVA. Testing the influence of phenological phase on grassland biomass chemical composition and cow milk characteristics was performed using LSD test. For statistical analysis of data program Statistica 10 (StatSoft, Tulsa, Oklahoma, USA) was used.

\section{Statement of institutional animal care}

Experiment was performed in accordance with the Act Nr 14/2008, on the Protection of Animal Welfare of the Montenegro. With regard to the type of study, no special permission was required.

\section{RESULTS AND DISCUSSION}

Vegetation of this pasture was represented by an Agrostis castellana community. The community consisted of 51 species, belonging to 50 genera and 21 families. In the general taxonomical spectrum of families dominant were Poaceae (11 species), Asteraceae (7 species), Fabaceae, Rosaceae (5 species each), and Apiacea (4 species), while among genera the most representatives had genus Allium and Carex (2 species each). Other genera had a single representative.

Group of dominant species consisted of: A. castellana, Anthoxanthum odoratum, Bothriochloa ischaemum, Dactylis glomerata, Dasypyrum villosum, Lotus corniculatus, Medicago sativa, Phleum pratense, Pilosella bauhinii, Plantago lanceolata, Sanguisorba minor, Trifolium ochroleucon (Table 1). Observed by the aspects, the floristic composition varied considerably. Some plants were present in the reproductive phase on the pasture during all three sampling phases (e.g. A. odoratum, Centaurea jacea subsp. angustifolia, Crepis biennis, D. glomerata, L. corniculatus, $M$. sativa, Potentilla recta, T. ochroleucon), while some were typical for particular phase, i.e. aspect of the plant community.

The first aspect of flora is characterized by 40 species. Daisies (fam. Asteraceae) participated with 17.5\%, legumes (fam. Fabaceae), grasses (fam. Poaceae) and umbellifers (fam. Apiaceae) with 10\% each. The highest cover values had 
Table 1. Floristic composition and plant community structure in different phases. Plots: I, II, III; floristic aspects 1, 2, 3 (April, May, July); Braun-Blanquet cover scale: r, +, 1, 2, 3, 4. Only species with cover value equal or bigger than 1 are given in the table.

\begin{tabular}{|c|c|c|c|c|c|c|c|c|c|c|}
\hline \multirow[b]{2}{*}{ Family } & \multirow[b]{2}{*}{ Species } & \multicolumn{3}{|c|}{1} & \multicolumn{3}{|c|}{2} & \multicolumn{3}{|c|}{3} \\
\hline & & I & II & III & I & II & III & I & II & III \\
\hline Poaceae & Agrostis castellana & - & - & - & - & 3 & 1 & 1 & 3 & 1 \\
\hline Poaceae & Anthoxanthum odoratum & 1 & 2 & 1 & 1 & 1 & 2 & 1 & 1 & 1 \\
\hline Caryophyllaceae & Aremonia agrimonoides & 1 & + & + & 1 & + & + & + & 1 & 1 \\
\hline Poaceae & Bothriochloa ischaemum & - & - & - & - & - & - & + & 2 & 2 \\
\hline Poaceae & Bromus racemosus & - & - & - & + & - & 1 & - & - & + \\
\hline Cyperaceae & Carex caryophyllea & 1 & - & 1 & 1 & - & 1 & 1 & - & 1 \\
\hline Asteraceae & Centaurea jacea subsp. angustifolia & + & + & + & 1 & + & + & 1 & 1 & 1 \\
\hline Asteraceae & Crepis biennis & 1 & 1 & 1 & 1 & 1 & 1 & + & + & - \\
\hline Poaceae & Dactylis glomerata & 1 & 2 & 2 & 2 & 2 & 1 & 2 & 2 & 1 \\
\hline Poaceae & Dasypyrum villosum & - & - & - & 3 & 2 & 2 & 2 & 1 & + \\
\hline Rosaceae & Filipendula vulgaris & 1 & + & - & 1 & + & - & + & 1 & - \\
\hline Fabaceae & Lathyrus tuberosus & 1 & - & - & 1 & - & - & 1 & - & - \\
\hline Fabaceae & Lotus corniculatus & 3 & 2 & 2 & 3 & 2 & 2 & 3 & 2 & 1 \\
\hline Malvaceae & Malva sylvestris & - & - & - & 1 & - & - & + & - & - \\
\hline Fabaceae & Medicago sativa & 2 & 1 & 1 & 2 & 1 & 1 & 1 & 1 & 1 \\
\hline Fabaceae & Ononis spinosa & 1 & - & - & 1 & - & - & 1 & - & - \\
\hline Poaceae & Phleum pratense & - & - & - & - & 2 & 1 & + & 2 & 1 \\
\hline Asteraceae & Pilosella bauhini & + & 2 & + & - & + & + & - & - & - \\
\hline Plantaginaceae & Plantago lanceolata & 1 & 2 & 1 & + & + & + & + & - & - \\
\hline Poaceae & Poa pratensis & 1 & + & - & - & - & - & - & - & - \\
\hline Rosaceae & Potentilla recta & + & + & + & + & + & + & 1 & + & + \\
\hline Ranunculaceae & Ranunculus neapolitanus & 1 & 1 & 1 & + & + & + & - & - & - \\
\hline Orobanchaceae & Rhinanthus mediterraneus & + & + & + & + & 1 & 1 & + & 1 & 1 \\
\hline Rosaceae & Sanguisorba minor & 2 & 2 & + & 2 & 1 & + & + & + & + \\
\hline Aoiaceae & Seseli montanum subsp. tommasinii & 1 & + & - & 1 & + & - & 1 & + & - \\
\hline Fabaceae & Trifolium ochroleucon & 2 & 1 & + & 2 & 1 & 1 & + & 1 & 1 \\
\hline Plantaginaceae & Veronica austriaca & 1 & + & + & 1 & - & - & - & - & - \\
\hline
\end{tabular}

L. corniculatus, M. sativa, D. glomerata, S. minor, A. odoratum, P. lanceolata, T. ochroleucon. Floristic composition and structure of plant community in different phases is given in the Table 1.

In the second floristic aspect 44 species were reported. Participation of grasses increased on 20.5\%, and some additional species appeared: Aegilops geniculata, A. castellana, D. villosum, and Phleum pretense. Daisies participated in the spectrum with $13.6 \%$ and legumes with $11.4 \%$. High cover values had: A. castellana, D. glomerata, D. villosum, $L$. corniculatus, and M. sativa.

The third aspect included the same number of species like the first one (40), but the spectrum differed significantly. Grasses participated in the spectrum with $25 \%$, legumes with $12.5 \%$, and daisies with $7.5 \%$. Third aspect of flora is characterized by appearance of the late summer xerophilic xerophytic grass $B$. ischaemum.

The pastures in this area are extensively used for years, and no agrotechnical measures are applied. So far, there were no botanical records on floristic composition of such vegetation type in Montenegro, even in Southeast Europe. Due to abundance of the grasses D. glomerata and A. odoratum, in addition to legumes such as L. corniculatus and Medicago sativa, the A. castellana plant community could be assessed as moderate to good quality.

Observed by phases, the floristic composition varied considerably. Some plants were present in the pasture during all three phases (A. odoratum, C. jacea subsp. angustifolia, C. biennis, D. glomerata, L. corniculatus, M. sativa, P. recta, $T$. ochroleucon). Those plants are known as high quality pasture species. On the other hand, some plants finished their life cycle already with the first aspect (e.g. Carex caryophyllea), while some of them reached reproductive phase during the second or third aspect (e.g. A. castellana, Convolvulus arvensis, P. pratense, Lithospermum officinale). The participation of plants which are readily consumed by the animals gradually decreased during the experimental period. Pelve (2010) described various types of pasture in Sweden and found that in the dry pastures dominate Festuca ovina, Hieracium pilosella, Galium verum, Lychnis viscaria and species of the family Crassulaceae. 
An increase in milk PUFAs concentration in pasture animals has been proven by many authors (Samková et al., 2018). The main nutritional n-3 precursor is $\alpha$-linolenic acid which makes about $50 \%-75 \%$ of the total FA content of fresh grass, depending on the pasture botanical composition and the phenological phase (Collomb et al., 2002). The increase in the content of conjugated linoleic acid in milk obtained from grazing animals is considered to be the result of the consumption of grasses rich in linoleic (C18:2) and $\alpha$-linolenic acid (C18:), precursors of conjugated linoleic acid. The highest level is in plants at the first cut, and then it decreases during summer, particularly around flowering. It is known that changes in nutritional value, depending on species, are generally higher in grasslands rich in the Poaceae family than in those rich in Fabaceae (Farruggia et al., 2008).

Revello-Chion et al. (2011) described the Alpine pastures at altitude of 1200 to $1600 \mathrm{~m}$ found the presence of over 30 plant species. Poaceae were the most excited family ( $43 \%$ and $37 \%$ of the total species) and the main representatives were D. glomerata, and Festuca gr. rubra. Fabaceae took part about $27 \%$ and $28 \%$. In our research, the proportion of these species is much lower. They found also that Poaceae $\left(65.6 \mathrm{~g} \mathrm{~kg}^{-1} \mathrm{DM}\right)$, followed by Fabaceae $\left(54.7 \mathrm{~g} \mathrm{~kg}^{-1} \mathrm{DM}\right)$ had the highest proportion of PUFAs, while Fabaceae had the highest content of the total FA. Coppa et al. (2011) consider pasture with 71 species very rich, while those with around 30 species are medium-diversified. According to this description, our pasture with 51 species can be qualified as botanically diversified pasture.

The concentration of $\mathrm{C} 18: 3$ is higher in grasses than in legumes. Lipids are found in chloroplasts of the leaf, and a high percentage of leaves in the diet can lead to a large intake of C18:3. The explanation for the differences in the content of C18:1 and C18:2 in grazing at different times is the different botanical composition and phenological phase of the plants (Elgersma et al., 2006).

\section{Chemical composition of the pasture biomass}

The chemical composition of the pasture biomass has been changed throughout the grass phenological phases, as expected. The results of the pasture chemical analysis are given in Table 2. The DM content increased during research period. Differences are significant among all phases $(\mathrm{p}<0.05)$. The content of total DM and, total crude fibers and fat content increase during the experimental period and differences were significant among tested phenological phases. The low DM content that results in reduced energy intake is the main limiting factor for high milk production in pastures.

Significant differences were found in the protein content, but the protein content decreased during control. The difference in ash content was significant only in the third phase.

The obtained results of grass chemical composition are in accordance with Bovolenta et al. (2008), who found that proportions of structural carbohydrates, such as cellulose, hemicelluloses and lignin increase with plant growth, while protein content declines. Bohacová et al. (2009) examined the change in the chemical composition of pasture and revealed a decrease in protein content and an increase in cellulose content in different phonological phases and they found lower content of crude fibers. Pelve (2010) indicates a reduction in nutritional value of biomass from all types of pasture, including dry pasture, depending on the season.

\section{Chemical composition of milk}

The analysis includes the content of fat, protein, lactose and non-fat solids in milk. The fat content slightly increased during this period (3.54\%-3.86\%). Significant differences were found in the content of fat in the third phase. The protein content varied slightly (3.10\%-3.18\%). The phenological phase did not significantly affect content of protein. Content of lactose was very constant during this period $(4.38 \%-4.35 \%)$ and the influence of the phenological phase was nonsignificant. Nonfat solids consist of proteins, lactose and a small part of the minerals, so neither the phenological phase had any influence on its content (8.16\%-8.27\%). Average milk chemical composition in this period is given in Figure 1.

Table 2. Chemical composition of pasture biomass.

\begin{tabular}{|c|c|c|c|c|c|}
\hline Phenological phase & DM & Crude protein & Total fat & Crude fiber & Ash \\
\hline & & & $-\%$ & & \\
\hline 1 & $20.31 \pm 0.56 \mathrm{a}$ & $19.8 \pm 0.19 \mathrm{a}$ & $1.29 \pm 0.32 \mathrm{a}$ & $21.52 \pm 0.51 \mathrm{a}$ & $7.41 \pm 0.18 \mathrm{a}$ \\
\hline 2 & $29.4 \pm 0.38 b$ & $14.56 \pm 0.28 b$ & $1.44 \pm 0.09 b$ & $26.63 \pm 0.47 \mathrm{~b}$ & $6.78 \pm 0.21 \mathrm{a}$ \\
\hline 3 & $44.89 \pm 0.61 \mathrm{c}$ & $9.39 \pm 0.34 c$ & $1.56 \pm 0.21 \mathrm{c}$ & $31.79 \pm 0.64 \mathrm{c}$ & $5.24 \pm 0.37 b$ \\
\hline
\end{tabular}

Values followed by different letters have significant difference according to LSD test $(\mathrm{p}<0.05)$. Phenological phases: 1 early vegetative phase; 2 late vegetative phase; 3 reproductive phase. 
Figure 1. Milk chemical composition (average content of milk fat, protein, lactose and non-fat solids) through three phenological phases.

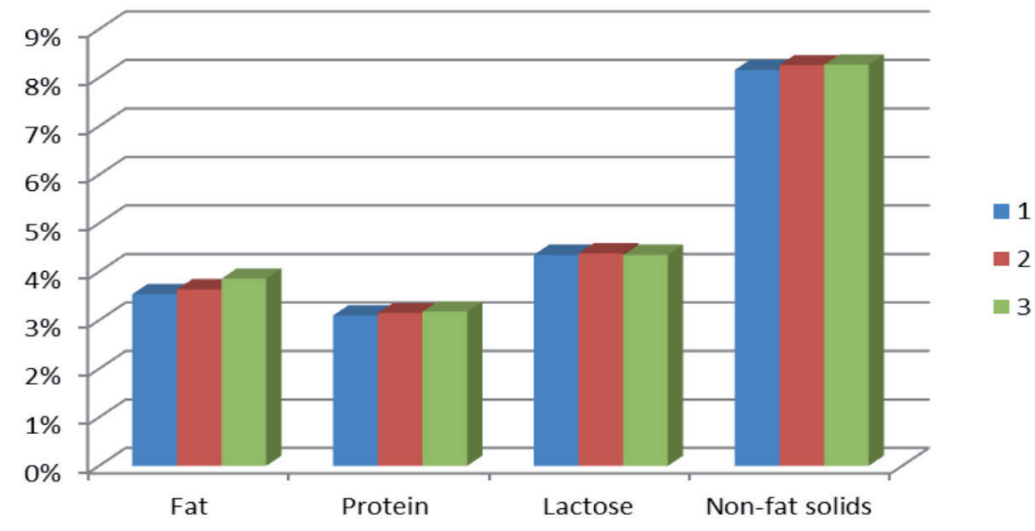

Phenological phases: 1 early vegetative phase; 2 late vegetative phase; 3 reproductive phase.

The content of the observed parameters in milk was quite good although it is a dry pasture. The value of the studied milk parameters was in range with results of some recent studies (Tratnik and Bozanic, 2012). Frelich et al. (2009) found higher fat content in cow milk from mountain pastures in Czech Republic. By examining the chemical composition of milk in different pastures (highly diversified and weakly diversified). Coppa et al. (2011) found that grazing management and herbage phenological phase seem to be more relevant for milk and cheese characteristics than pasture botanical composition.

Bohacová et al. (2009) reported that the content of milk fat increased with pasture biomass maturation. Similar results for protein content in milk in alpine pasture are reported by Gorlier et al. (2012) and Rodríguez-Bermúdez et al. (2017). The obtained results of protein content in milk of grazing cows are in line with Frelich et al. (2009), but on different type of pasture (Lolio-Cynosuretum association). Cow milk protein and lactose content is quite constant (Coppa et al., 2015), which is confirmed with our results.

The obtained results on the chemical composition of milk are similar to numerous results that have been carried out on different types of pastures, but there are no results from this type of A. castellana dry pasture.

\section{Fatty acid composition}

Saturated fatty acids. The content of 35 FAs was determined, of which 17 were saturated. The content of all FAs is given in Table 3. In the first phase, the total SFAs content was 68.63\%. The highest amount has C16:0, then C18:0 and C14:0. More than 1\% has C10:0, C12:0 and C15:0 while other SFAs account for less than 1\% of the total FA content. The total content of SFAs increased in the second phase $(69.98 \%)$ with a similar share of individual FAs.

The highest content of SFAs was recorded in the third phase, $89.23 \%$. This increase is mostly reflected in the increase in short-chain FAs and the increased participation of those most prevalent in previous phases. Fatty acids C4:0 to C10:0 increased through phases, while $\mathrm{C} 11: 0$ and $\mathrm{C} 20: 0$ decreased from first to third phase. Four FAs, C17:0, C22:0, C23:0 and C24:0 had the highest content in second phase, and then a slight decrease in the third phase. The concentration of 16:0 at the third period is very high. In general, it seems that there is a greater relevance of de novo FA synthesis at that period and a reduction in long chain FA uptake. A significant influence of the phenological phase was found for the majority of SFAs just in the third phase.

The total amount of SFAs is in line with the results of MacGibbon and Taylor (2006), Ferlay et al. (2008) who reported about 70\% SFA in cow milk. Ferlay et al. (2008) found stabile C6:0, C8:0 and C10:0 content during grazing period, while we found significant increase in third phase. They also found slightly decrease in C14:0 content, but we have stabile content in first two phases and significant increase in the third one. They found slightly decrease in C16:0 content from spring to autumn, which is not in line with our results. This can be explained by a significantly longer interval between the first and third phase in this research in relation to the phases in their research and different type of pasture, also. 
Table 3. Milk fatty acid (FA) content ( $\%$ of total FAME) in three phenological phases.

\begin{tabular}{|c|c|c|c|}
\hline \multirow[b]{3}{*}{ FA } & \multicolumn{3}{|c|}{ Phenological phase } \\
\hline & 1 & 2 & 3 \\
\hline & Mean \pm SD & Mean \pm SD & Mean \pm SD \\
\hline \multicolumn{4}{|c|}{ SFA } \\
\hline $\mathrm{C} 4: 0$ & $0.92 \pm 0.14 \mathrm{~ns}$ & $0.91 \pm 0.13 \mathrm{~ns}$ & $1.76 \pm 0.41 *$ \\
\hline C6:0 & $0.99 \pm 0.11 \mathrm{~ns}$ & $0.99 \pm 0.17 \mathrm{~ns}$ & $2.09 \pm 0.40 *$ \\
\hline C8:0 & $0.83 \pm 0.11 \mathrm{~ns}$ & $0.83 \pm 0.18 \mathrm{~ns}$ & $1.49 \pm 0.32 *$ \\
\hline C10:0 & $2.06 \pm 0.38 \mathrm{~ns}$ & $2.12 \pm 0.53 \mathrm{~ns}$ & $3.41 \pm 0.83^{*}$ \\
\hline C11:0 & $0.17 \pm 0.05 \mathrm{~ns}$ & $0.17 \pm 0.05 \mathrm{~ns}$ & $0.14 \pm 0.05^{*}$ \\
\hline C12:0 & $2.64 \pm 0.45 n s$ & $2.76 \pm 0.64 \mathrm{~ns}$ & $3.93 \pm 0.90 *$ \\
\hline C13:0 & $0.11 \pm 0.02 \mathrm{~ns}$ & $0.11 \pm 0.03 \mathrm{~ns}$ & $0.14 \pm 0.03 *$ \\
\hline C14:0 & $11.02 \pm 0.85 \mathrm{~ns}$ & $11.42 \pm 0.84 \mathrm{~ns}$ & $14.79 \pm 0.80 *$ \\
\hline C15:0 & $1.76 \pm 0.29 \mathrm{~ns}$ & $1.81 \pm 0.18 \mathrm{~ns}$ & $2.19 \pm 0.49 *$ \\
\hline C16:0 & $30.34 \pm 1.62 \mathrm{~ns}$ & $30.73 \pm 1.32 \mathrm{~ns}$ & $39.65 \pm 1.90 *$ \\
\hline C17:0 & $1.29 \pm 0.21 \mathrm{~ns}$ & $1.35 \pm 0.18 \mathrm{~ns}$ & $1.27 \pm 0.32 *$ \\
\hline C18:0 & $15.45 \pm 1.34 \mathrm{~ns}$ & $15.70 \pm 1.76 \mathrm{~ns}$ & $17.65 \pm 1.32 *$ \\
\hline C20:0 & $0.35 \pm 0.10 \mathrm{~ns}$ & $0.33 \pm 0.08 \mathrm{~ns}$ & $0.30 \pm 0.07 \mathrm{~ns}$ \\
\hline $\mathrm{C} 21: 0$ & $0.05 \pm 0.01 \mathrm{~ns}$ & $0.05 \pm 0.00 \mathrm{~ns}$ & $0.08 \pm 0.02$ \\
\hline $\mathrm{C} 22: 0$ & $0.29 \pm 0.07 \mathrm{~ns}$ & $0.31 \pm 0.04 \mathrm{~ns}$ & $0.13 \pm 0.03 *$ \\
\hline $\mathrm{C} 23: 0$ & $0.18 \pm 0.06 n s$ & $0.20 \pm 0.04 \mathrm{~ns}$ & $0.07 \pm 0.02 *$ \\
\hline $\mathrm{C} 24: 0$ & $0.12 \pm 0.05 \mathrm{~ns}$ & $0.12 \pm 0.03 \mathrm{~ns}$ & $0.07 \pm 0.02 *$ \\
\hline & 68.63 & 69.98 & 89.23 \\
\hline \multicolumn{4}{|c|}{ MUFA } \\
\hline $\mathrm{C} 14: 1$ & $0.64 \pm 0.25 n s$ & $0.71 \pm 0.25 \mathrm{~ns}$ & $0.33 \pm 0.12 *$ \\
\hline C16:1 & $1.18 \pm 0.25 n s$ & $1.12 \pm 0.29 \mathrm{~ns}$ & $0.54 \pm 0.12 *$ \\
\hline $\mathrm{C} 18: \ln 9 \mathrm{c}$ & $26.23 \pm 1.86 \mathrm{~ns}$ & $24.88 \pm 1.07 \mathrm{~ns}$ & $8.54 \pm 0.54 *$ \\
\hline & 28.37 & 27.02 & 9.71 \\
\hline \multicolumn{4}{|c|}{ PUFA } \\
\hline C18:3n3 & $1.08 \pm 0.36 \mathrm{~ns}$ & $1.20 \pm 0.22 \mathrm{~ns}$ & $0.55 \pm 0.17 *$ \\
\hline $\mathrm{C} 18: 2 \mathrm{n} 6 \mathrm{c}$ & $2.11 \pm 0.31 \mathrm{~ns}$ & $1.98 \pm 0.25 \mathrm{~ns}$ & $0.70 \pm 0.15^{*}$ \\
\hline C20:3n6 & $0.05 \pm 0.01 \mathrm{~ns}$ & $0.06 \pm 0.01 \mathrm{~ns}$ & $0.05 \pm 0.00 *$ \\
\hline $\mathrm{C} 20: 5 \mathrm{n} 3$ & $0.08 \pm 0.03 \mathrm{~ns}$ & $0.09 \pm 0.02 \mathrm{~ns}$ & $0.05 \pm 0.00 *$ \\
\hline & 3.59 & 3.59 & 1.61 \\
\hline
\end{tabular}

* Significant difference between mean values $\mathrm{p}<0.05$.

SFA: Saturated fatty acids; MUFA: monounsaturated fatty acids; PUFA: polyunsaturated fatty acids; FAME: fatty acid methyl esters; ns: nonsignificant differences.

Phenological phases: 1 early vegetative phase; 2 late vegetative phase; 3 reproductive phase.

The increase in C16:0 concentrations in milk can be related to the increase in C16:0 concentrations in herbage during maturation (Revello-Chion et al., 2011; Glasser et al., 2013). Significant differences between SFA content in spring and summer are reported by Bohacová et al. (2009). They found lower SFAs content in May and the increase to the end of season was small. This increase in our research was much higher. Rutkowska et al. (2012) suggest decrease in SFAs content in the summer compared to spring in mountain region in Poland, which is not in range with our results.

Many authors indicate the lowest content of SFAs in milk of cows fed with young pasture in different regions in France, Czech Republic, Poland and Switzerland (Collomb et al., 2008; Frelich et al., 2009), but without description of pasture type and its floristic composition.

In our study, the concentration of C18:0 was very high in all phases, and has increased in the third phase. The differences among sampling dates in the content of SFA in the listed studies are not as large as in our research, although they exist. The reason for this can be the use of grazing only, without additional feeds, in the third phase, when the pasture has already been matured.

Monounsaturated fatty acids. The content of nine MUFAs was determined. In the first phase, the total content of MUFAs was $28.37 \%$. The largest share has $\mathrm{C} 18: 1 \mathrm{n} 9 \mathrm{c}, 26.23 \%$. The total content of MUFAs decreased in the second phase $(27.02 \%)$ with a similar share of individual FAs. The lowest content of MUFAs was recorded in the third phase of 
9.71\%. Five MUFAs were present in traces (C15:1, C17:1, C20:1, C22:1n9, C 18:1n9t, C24:1). The highest content in second phase has $\mathrm{C} 14: 1$. The greatest decrease was in $\mathrm{C} 18: 1 \mathrm{n} 9 \mathrm{c}$. A significant influence of the phenological phase was found for all MUFAs just in the third phase. This is not the total MUFA in milk, as most trans and cis 18:1 isomers were not quantified.

Rutkowska et al. (2012) found higher content of MUFAs in the summer period compared to the spring in the milk of cows grazing on mountain pastures in Beskid Mountains, Poland. As a main reason, they indicate a change in the composition of FAs in the pasture biomass in different phases. Also the most commonly MUFA was C18:1n9c. MacGibbon and Taylor (2006) reported lower content of C18:1n9c. They explain this with high level of 18:2 and 18:3 in the fresh grass. Those acids as a result of the reaction of biohydrogenation and desaturation, lead to an increase in the levels of 18:0 and 18:1 in the cow's milk fat. Similar results on MUFAs content were reported by Ferlay et al. (2008).

Polyunsaturated fatty acid. The content of nine PUFAs was determined. In the first phase, the total content of PUFAs was $3.59 \%$. The largest amount has C 18:2n6c and C 18:3n3, while other PUFAs account for less than $1 \%$ of the total FA content. These two acids are also the most important PUFAs. The total content of PUFA was almost the same in the second phase with a similar share of individual FA. The lowest PUFAs content was recorded in the third phase, only 1.61\%. Five PUFAs were present in traces (C18:3n6, C18:2n6t, C20:2, C20:3n3, C22:2). Three FAs, C 18:3n3, C 20:3n6 i C 20:5n3 had the highest content in the second phase, and slight decrease in the third phase. A significant influence of the phenological phase was found just for all PUFAs in the third phase.

Due to the high content of cellulose in biomass in the third phase, the content of fat in milk has increased, but the content of PUFAs has been reduced and the content of SFAs increased, which is not desirable. A significant number of preferred FAs had the highest participation in the second phase, which means that in this phase, milk is retained by the desired FA composition, even better than in the first phase. The differences between the first and second phase were very small and it can be concluded that this type of pasture, although it is a dry pasture, has a positive influence on the quality of milk during spring and early summer.

Fresh grass contains a high proportion (50\%-75\%) of total FA content in the form of n-3 linolenic acid (Descalzo et al., 2012). This is a reason for the highest content of PUFAs in early vegetative phase. Due to the differences in PUFAs intake, the total PUFAs content in milk tended to fluctuate throughout the year. The feeding regime based only on grazing led to increasing the content of $\alpha$-linolenic acid in milk fat, and the resulting biohydrogenated FA, conjugated linoleic acid (CLA) and vaccenic acid (Collomb et al., 2008). The main source of milk CLA is not ruminal biohydrogenation but mammary desaturation of vaccenic acid.

Ferlay et al. (2008) reported similar results of the PUFAs content in cow's milk in Central France, but the type of pasture was not described. Coppa et al. (2015) indicate a significant influence of the phenological phase on the PUFA content in grazing cows. Different results are reported by Rutkowska et al. (2012), who found a significant increase in PUFAs content in the summer compared to spring, but on different type of pasture. Reduction of the C18: $3 \mathrm{n} 3$ in biomass with maturation of pasture is reported by Revello-Chion et al. (2011) and Glasser et al. (2013).

Roca-Fernandez et al. (2012) indicate a significant increase of PUFAs content and a decrease of SFAs in milk of cows fed only with pasture in the summer period in Spain. The highest content of PUFAs in milk of cows fed with young pasture in the spring period is confirmed by Frelich et al. (2009), Bohacová et al. (2009), and Gorlier et al. (2012), showed that the phenological phase affects the composition of FAs in cow milk on mountain pastures.

In many studies, the PUFAs content decreased after an early vegetative phase. In our research, the same PUFAs content kept up to the reproductive stage. The reason for this is the favorable floristic composition and the chemical composition of pasture biomass in the second phase, which has not yet become rough and the leaves content was still high.

\section{CONCLUSIONS}

No much data exist for quality of dry grassland in Europe and related effects on milk chemical characteristics and milk yield. In our study, it was shown that milk quality, protein and fat content were the highest in the third phase of grazing grassland. This can partly justify keeping cows grazing so late, which is economically very important for farmers, especially in the extensive livestock system. On the other side, milk fatty acid composition decreased in this phase, which 
imposes the need to improve animal feeding in this period. Our results indicate an importance of maintain dry grasslands, since pastures are crucial in ruminant nutrition, and the large part of the total gathered milk is obtained directly from that natural resource. The further efforts should be put on the research of other pastoral areas of Montenegro.

\section{REFERENCES}

AOAC. 2000. Method number 991.20; 33.2.11. Official methods of analysis of AOAC International. 17 $7^{\text {th }}$ ed. Association of Analytical Communities (AOAC) International, Gaithersburg, Maryland, USA.

AS-1064. 2012. Sampling feed for analysis. North Dakota State University, Fargo, North Dakota, USA.

Bohacová, L., Dvoraková, E., Cermák, B., Spicka, J., and Vávrová, L. 2009. The effect of the structure of the pasture growth on the substitution of fatty acids in the milk of grazing dairy cow. Zootehniesi Biotehnologii 42(2):225-231.

Bovolenta, S., Spanghero, M., Dovier, S., Orlandi, D., and Clementel, F. 2008. Chemical composition and net energy content of alpine pasture species during the grazing season. Animal Feed Science and Technology 140(1-2):164-177.

Braun-Blanquet, J. 1964. Pflanzensoziologie. Grundzuge der Vegetationskunde. $3^{\text {rd }}$ ed. Springer, Wien, Austria.

Chilliard, Y., Glasser, F., Ferlay, A., Bernard, L., Rouel, J., and Doreau, M.D. 2007. Rumen biohydrogenation and nutritional quality of cow and goat milk fat. European Journal of Lipid Science and Technology 109:828-855.

Collomb, M., Bisig, W., Bütikofer, U., Sieber, R., Bregy, M., and Etter, L. 2008. Fatty acid composition of mountain milk from Switzerland: comparison of organic and integrated farming systems. International Dairy Journal 18:976-982.

Collomb, M., Bütikofer, U., Sieber, R., Jeangros, B., and Bosset. J.O. 2002. Composition of fatty acids in cow's milk fat produced in the lowlands, mountains and highlands of Switzerland using high-resolution gas chromatography. International Dairy Journal 12:649-659.

Coppa, M., Chassaing, C., Ferlay, A., Agabriel, C., Laurent, C., and Borreani, G. 2015. Potential of milk fatty acid composition to predict diet composition and authenticate feeding systems and altitude origin of European bulk milk. Journal of Dairy Science 98:1539-1551.

Coppa, M., Ferlay, A., Monsallier, F., Verdier-Metz, I., Pradel, P., Didienne, R., et al. 2011. Milk fatty acid composition and cheese texture and appearance from cows fed hay or different grazing systems on upland pastures. Journal of Dairy Science 94:1132-1145.

Descalzo, A.M., Rossetti, L., Paez, R., Grigioni, G., Garcia, P.T., Costabel, L., et al. 2012. Differential characteristics of milk produced in grazing systems and their impact on dairy products. p. 339-368. In Chaiyabutr, N. (ed.) Milk production. Advanced genetic traits, cellular mechanism, animal management and health. IntechOpen, London, UK.

Elgersma, A., Tamminga, S., and Dijkstra, J. 2006. Lipids in herbage: their fate in the rumen of dairy cows and implications for milk quality. p. 175-194. In Elgersma, A., Tamminga, S., Dijkstra, J. (eds.) Fresh herbage for dairy cattle: the key to a sustainable food chain. Wageningen UR Frontis Series, Vol. 18. Springer, Dordrecht, Netherlands.

Euro+Med. 2006. Euro+Med PlantBase - the information resource for Euro-Mediterranean plant diversity. Available at http://ww2.bgbm.org/EuroPlusMed/ (accessed June 2018).

Farruggia, A., Martin, B., Baumont, R., Prache, S., Doreau, M., Hoste, H., et al. 2008. Quels intérêts de la diversité floristique des prairies permanentes pour les ruminants et les produits animaux? INRA Productions Animales 21:181-200.

Ferlay, A., Agabriel, C., Sibra, C., Journal, C., Martin, B., and Chilliard, Y. 2008. Tanker milk variability of fatty acids according to farm feeding and husbandry practices in a French semi-mountain area. Dairy Science and Technology 88:193-215.

Frelich, J., Slachta, M., Hanus, O., Spicka, J., and Samková, E. 2009. Fatty acid composition of cow milk fat produced on lowinput mountain farms. Czech Journal of Animal Science 12:532-539.

Fustic, B., and Djuretic, G. 2000. Soils of Montenegro. p. 115-122. University of Montenegro, Biotechnical Faculty, Podgorica, Montenegro.

Glasser, F., Doreau, M., Maxin, G., and Baumont, R. 2013. Fat and fatty acid content and composition of forages: a metaanalysis. Animal Feed Science and Technology 185:19-34.

Gorlier, A., Lonati, M., Renna, M., Lussiana, C., Lombardi, G., and Battaglini, L.M. 2012. Changes in pasture and cow milk compositions during a summer transhumance in the western Italian Alps. Journal of Applied Botany and Food Quality $85: 216-223$.

Hanus, O., Krízová, L., Samková, E., Spicka, J., Kucer, J., Klimesová, M., et al. 2016. The effect of cattle breed, season and type of diet on the fatty acid profile of raw milk. Archives Animal Breeding 59:373-380.

IDF Standard 141C. 2000. Whole milk. Determination of milk fat, protein and lactose content - Guide for the operation of mid infrared instruments. International Dairy Federation (IDF), Brussels, Belgium.

ISO-IDF. 2002. International standard ISO 15885:2002. Milk fat - Determination of the fatty acid composition by gas-liquid chromatography. International Organization for Standardization (ISO), Geneva, Switzerland, and International Dairy Federation (IDF), Brussels, Belgium.

ISO-IDF. 2008. International standard ISO 707-IDF 50. Milk and milk products - Guidance on sampling. International Organization for Standardization (ISO), Geneva, Switzerland, and International Dairy Federation (IDF), Brussels, Belgium. 
MacGibbon, A.H.K, and Taylor, M.W. 2006. Composition and structure of bovine milk lipids. p. 142. In Fox, P.F., and McSweeney, P.L.H. (eds.) Advanced dairy chemistry. Springer, New York, USA.

Monstat. 2016. Stocni fond. Statistical office of Montenegro (Monstat), Podgorica, Montenegro.

Pelve, M. 2010. Cattle grazing on semi-natural pastures - animal behaviour and nutrition, vegetation characteristics and environmental aspects. Licentiate thesis. Swedish University of Agricultural Sciences, Uppsala, Sweden.

Revello-Chion, A., Tabacco, E., Peiretti, P.G., and Borreani, G. 2011. Variation in the fatty acid composition of alpine grassland during spring and summer. Agronomy Journal 103:1072-1080.

Roca-Fernandez, A.I., Gonzalez-Rodriguez, A., Vazquez-Yanez, O.P, and Fernandez-Casado, J.A. 2012. Effect of forage source (grazing $v s$. silage) on conjugated linoleic acid content in milk fat of Holstein-Friesian dairy cows from Galicia (NW Spain). Spanish Journal of Agricultural Research 10(1):116-122.

Rodríguez-Bermúdez, R., Miranda, M., Orjales, I., Rey-Crespo, F., Muñoz, N., and López-Alonso, M. 2017. Holstein Friesian milk performance in organic farming in North Spain: Comparison with other systems and breeds. Spanish Journal of Agricultural Research 15(1):e0601. https://doi.org/10.5424/sjar/2017151-10037.

Rutkowska, J., Adamska, A., and Bialek, M. 2012. Fatty acid profile of the milk of cows reared in the mountain region of Poland. Journal of Dairy Research 79:469-476.

Samková, E., Koubová, J., Hasonova, L., Hanus, O., Kala, R., Kvác, M., et al. 2018. Joint effects of breed, parity, month of lactation, and cow individuality on the milk fatty acids composition. Mljekarstvo 68(2):98-107.

Sasanti, B., Abel, S., Muller, C.J.C., Gelderblom, W.C.A., and Schmulian, A. 2015. Milk fatty acid composition and conjugated linoleic acid content of Jersey and Fleckvieh $\times$ Jersey cows in a pasture-based feeding system. South African Journal of Animal Science 45(4):411-418.

Stesevic, D., and Cakovic, D. 2013. Katalog vaskularne flore crne gore. Vol. I. Crnogorska Akademija Nauka I Umjetnosti (CANU), Podgorica, Montenegro.

Tratnik, Lj., and Bozanic, R. 2012. Mlijeko i mliječni proizvodi. 510 p. Hrvatska mljekarska udruga, Zagreb, Croatia.

Tutin, T.G., Heywood, V.H., Burges, N.A., Moore, D.M., Valentine, D.H., Walters, S.M., et al. 1964-1993. Flora Europaea. Vol. I-V. Cambridge University Press, Cambridge, UK. 